\section{Lesão Pulmonar Cavitaria}

\section{Cavitary pulmonary lesion}

A lesão pulmonar cavitária é uma área pulmonar preenchida por ar no centro de um nódulo ou área consolidada ${ }^{1}$, identificada habitualmente pela radiografia de tórax ou tomografia computadorizada. Vários agentes infecciosos e não infecciosos têm sido implicados como seus possíveis precipitantes. Neoplasias e Infecção são as duas causas mais comuns nos adultos ${ }^{2}$. Dentro das causas infecciosas menos frequentes é o Haemophilus influenza ${ }^{1,2}$. Condições como tabagismo, alcoolismo, idade avançada, diabetes mellitus, doença pulmonar crónica ou doença hepática são factores de risco.

Os autores apresentam um caso clínico de um homem de 42 anos de idade, trabalhador da construção civil, com antecedentes pessoais de Tabagismo, Hepatite a vírus $\mathrm{C}$ crónica, e etanolismo. Internado por febre, calafrios, tosse com expectoração e toracalgia direita. Na radiografia do tórax observava-se imagem nodular com nível hidroaéreo no terço médio do hemitorax direito e hipotransparencia no segmento apical do lobo inferior esquerdo (imagem 1). Realizou TC do tórax que identificou imagem cavitaria, no lobo superior direito, de paredes espessas, rodeadas por halo periférico de densificação em vidro despolido do parênquima e densificação reticular do interstício, e tem um nível hidro-aéreo no seu interior, uma área de densificação do parênquima que parece já esboça incipiente cavitação ao nível do segmento apical do lobo inferior esquerdo. (imagem 2 e 3). Realizou-se Broncofibroscopia rigida e colheu secreções brônquicas e lavado bronco-alveolar para exame cultural bacteriológico. Isolou-se Haemophilus influenzae sensivel à Quinolonas, Inciado Levofloxacina que cumpriu 3 semanas, apresentando melhoria clínica e radiologica evidente (imagem 4 e 5).

\section{Bibliografia}

1. Gadkowski, L. Beth, and Jason E. Stout. "Cavitary pulmonary disease." Clinical microbiology reviews 21.2 (2008): 305-333.

2. Kim, Na Rae, and Joungho Han. "Pathologic review of cystic and cavitary lung diseases." Korean journal of pathology 46.5 (2012):407.

3. Pinto, C., et al. "Pneumonia necrotizante--a propósito de um caso clínico." RPDI-Revista Portuguesa de Doenças Infecciosas 10.1 (2014).

4. Ryu, Jay H., and Stephen J. Swensen. "Cystic and cavitary lung diseases: focal and diffuse." Mayo Clinic Proceedings. Vol. 78. No. 6Elsevier, 2003.

\section{Diagnóstico}

\section{Lesão Pulmonar Cavitaria causada por Haemophilus influenza}

Samaher Tannira, Eunice Oliveira, Francisco Silva, Alberto Mello e Silva

Serviço de Medicinia Il do Hospital Egas Moniz, CHLO.

Correspondencia: lazeza9000@hotmail.com

Como citar este artículo: Tannira S, Oliveira E, Silva F, Mello e Silva A Lesão Pulmonar Cavitaria causada por Haemophilus influenza. Galicia Clin 2016; 77 (2): 81

Recibido: 24/11/2015 ; Aceptado: 06/12/2015
Imagem 1. limagem nodular com nível hidroaéreo no terço médio do hemitorax direito e hipotransparencia no segmento apical do lobo inferior esquerdo
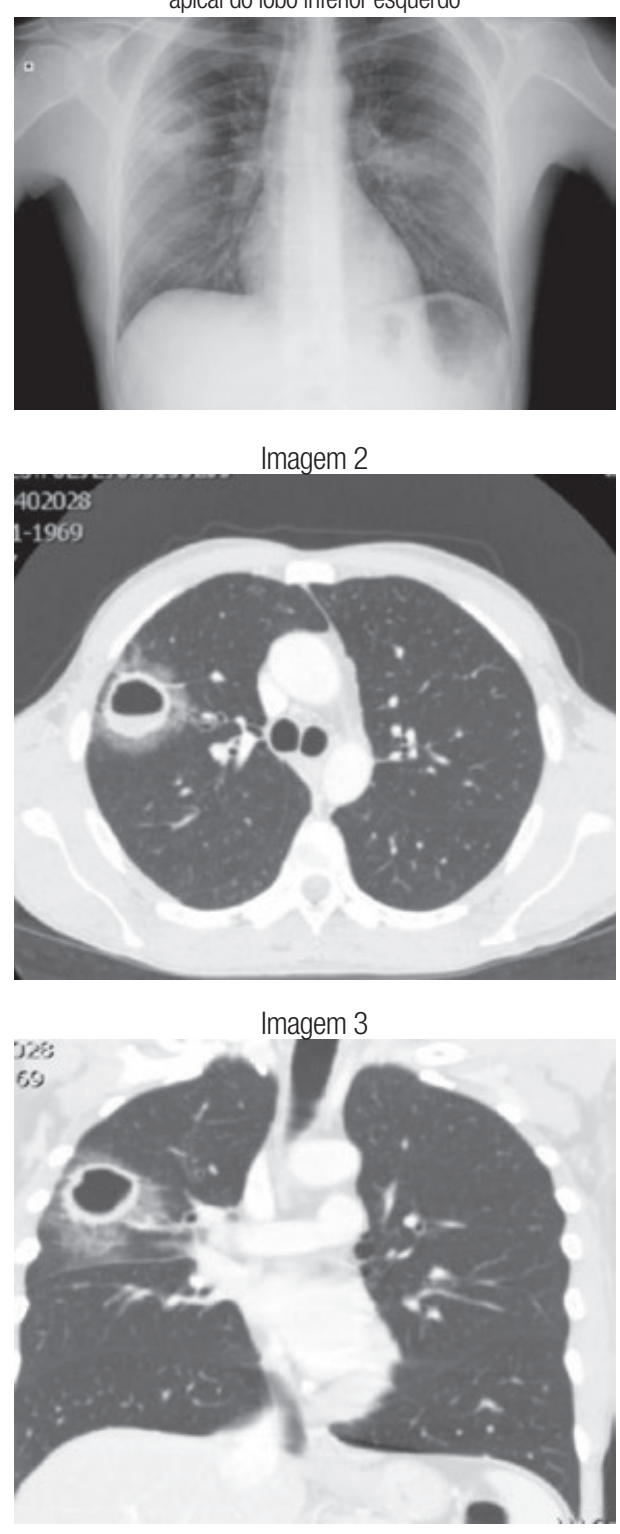

Imagem 4
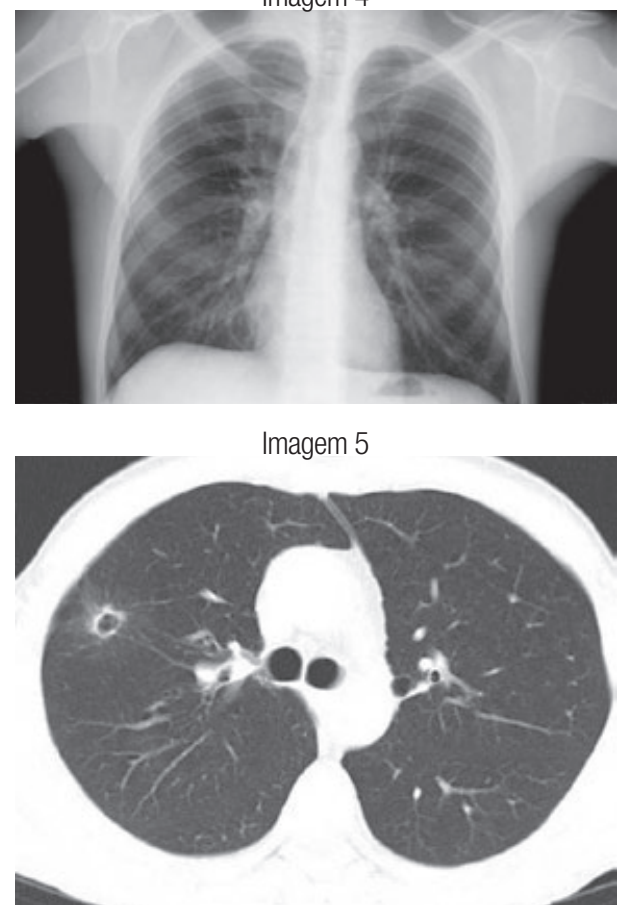